\title{
Removal of Heavy Metals from Steel Making Waste Water by Using Electric Arc Furnace Slag
}

\author{
C. L. BEH ${ }^{\mathrm{a}}$, T. G. CHUAH ${ }^{\mathrm{ab} *}$, M. N. NOUROUZI ${ }^{\mathrm{a}}$, AND THOMAS S.Y. CHOONG \\ ${ }^{a}$ Department of Chemical and Environmental Engineering, Faculty of Engineering, \\ Universiti Putra Malaysia, 43400 Serdang, Selangor, Malaysia \\ ${ }^{\mathrm{b}}$ Institute of Tropical Forestry and Forest Products (INTROP), Universiti Putra Malaysia, \\ 43400 Serdang, Selangor, Malaysia \\ chuah@eng.upm.edu.my
}

Received 25 June 2011; Accepted 15 August 2011

\begin{abstract}
This work investigated the reduction of chemical oxygen demand (COD), biological oxygen demand (BOD), total suspended solids (TSS) and the concentration of heavy metals of wastewater from a steel making plant. Adsorption experiments were carried out by electric arc furnace slag (EAFS) in a fixed-bed column mode. The raw wastewater did not meet the standard B limitations, having high values of BOD, COD, TSS, Iron, Zinc, Manganese and Copper. After passing through the fixed bed column, BOD, COD and TSS values decreased to $1.6,6.3$ and $<2 \mathrm{mgL}^{-1}$, respectively while the concentration of Iron, Zinc, Manganese and Copper were 0.08, 0.01, 0.03 and $0.07 \mathrm{mgL}^{-1}$, respectively. The results confirmed that EAFS can be used as an efficient adsorbent for producing treated water that comply with the Standard B limitations for an industrial effluent.
\end{abstract}

Keywords: Adsorption, electric arc furnace slag (EAFS), industrial wastewater, heavy metals.

\section{Introduction}

Generally, each steel mill in Malaysia uses an average of about $18000 \mathrm{~m}^{3}$ of water per day. This large amount of water is mainly used in the steel production for cooling purposes. The cooling process can be divided into two; indirect and direct cooling. Indirect cooling involves the cooling of equipment used in the steel production process as a series of heat exchanges and cooling the panels. On the other hand, a direct cooling (quenching) involves the cooling of the steel products produced from the steel making process to increase the strength of the steel by producing a specific microstructure. Furthermore, water is also used in the slag handling in the Electric Arc Furnaces, air pollution and impurity removal and scale breaking in the hot-rolling operations. Consequently, the wastewater from the steel production process has a high level of contamination containing a variety of heavy metal ions ${ }^{1}$. 
In general, the wastewater is discharged into the drainage system or pumped back into the clarifier pool before undergoing some conventional treatment such as chemical precipitation, activated carbon adsorption, ion exchange and membrane system ${ }^{2}$. However, wastewater from the steel mill contains a high concentration of heavy metals due to the accumulation of filtered particles from the filtration process of wastewater ${ }^{3}$. A direct release of the backwash water into the environment may cause serious effects to both land and aquatic lives. Metals are toxic and non-biodegradable and may continue to exist in these water bodies. The heavy metals also have the tendency to accumulate in the food chain. Hence, a strict environmental regulation has been established in an effort to mitigate the heavy metals contamination of the discharge of industrial effluent ${ }^{4-6}$.

The adsorption and precipitation process has been successfully applied to remove the heavy metals. The use of an activated carbon in the purification of an industrial wastewater is most suitable but rather expensive ${ }^{7}$. Hence low cost, long lasting, renewal adsorbent is being considered to remove the heavy metals. The electric arc furnace slag (EAFS) is a waste material generated from the steel making process. It is an attractive low cost yet effective material for the heavy metals removal, particularly manganese and copper removal in the steel industry waste water treatment process ${ }^{8}$.

The objective of this study is to investigate the EAFS as an effective absorbent for treating the industrial wastewater containing heavy metal ions in a fixed bed column. The main task of the study was to produce the treated wastewater which complies with the Standard B limitations for the discharge of industrial effluent or mixed effluent (Fifth Schedule to the Industrial Effluent Regulations, 2009) by Department of Environment (DOE) Malaysia.

\section{Experimental}

\section{Preparation of EAFS}

A set of electric arc furnace slag (EAFS) from the Southern Steel Berhad, Penang, Malaysia was crushed and grinded to $1 \mathrm{~mm}$. Table 1 presents the composition of EAFS. The sample slag was cleaned using distilled water and dried in the oven with a temperature of $100^{\circ} \mathrm{C}$ for 4 hours. The slag was then packed in a clear pipe column with an internal diameter of 100 $\mathrm{mm}$ and $1500 \mathrm{~mm}$ height. The bed height was set at $100 \mathrm{~cm}$.

Table 1. Composition of EAFS used in this work.

\begin{tabular}{lccccc} 
Composition & $\begin{array}{c}\text { Calcium } \\
\text { oxide }\end{array}$ & $\begin{array}{c}\text { Silicon } \\
\text { dioxide }\end{array}$ & $\begin{array}{c}\text { Ferum (II) } \\
\text { oxide }\end{array}$ & $\begin{array}{c}\text { Aluminium } \\
\text { oxide }\end{array}$ & $\begin{array}{c}\text { Magnesium } \\
\text { oxide }\end{array}$ \\
\hline Percentage $\%$ & 45.12 & 18.06 & 17.73 & 4.83 & 4.40 \\
\hline
\end{tabular}

\section{Sampling of steel mill wastewater}

The adsorbate was sampled by collecting about five liters of wastewater sample from the backwash water of the sand filter in the Southern Steel Berhad, Penang, Malaysia. It was then analyzed using the spectrophotometer according to the Standard Methods for the Examination of Water and Waste Water to determine the amount of heavy metals in the solution ${ }^{9}$. Figure 1 shows the point of sampling for the preparation of the adsorbate. 


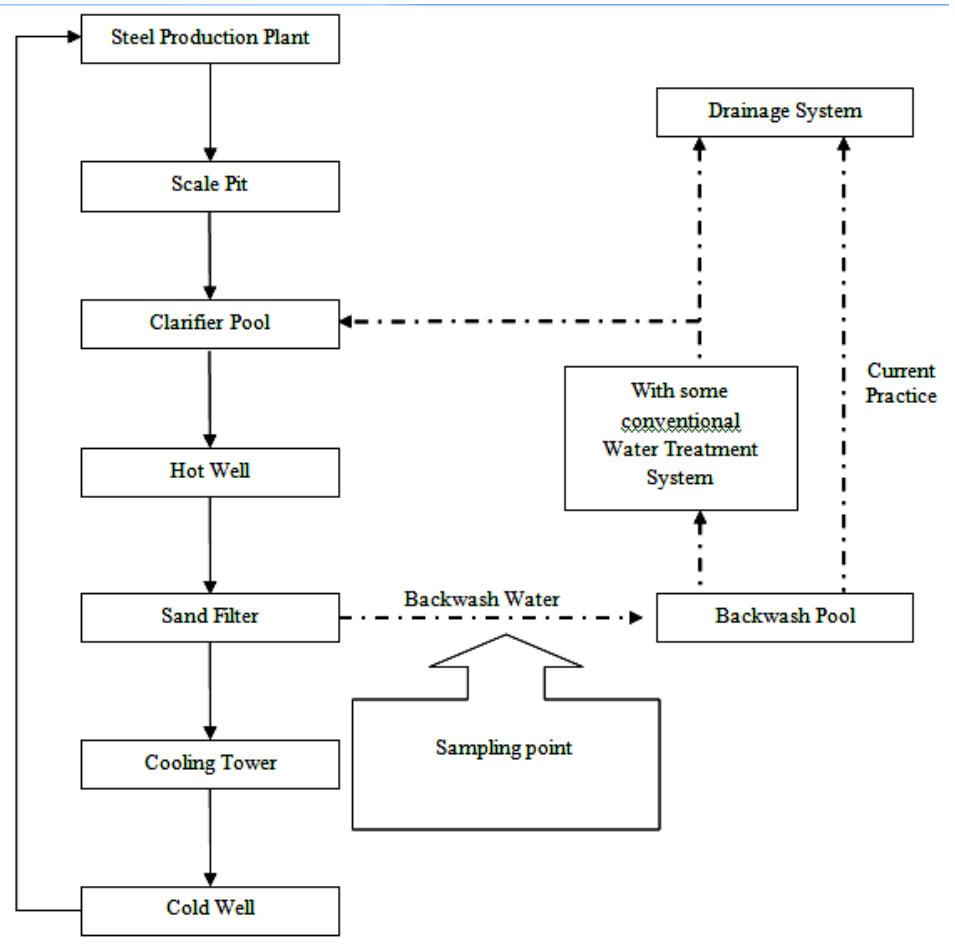

Figure 1. Point of sampling of the adsorbate.

\section{Column studies}

A fixed bed column experiment was carried out on the wastewater sample collected. The EAFS was packed in a clear pipe column of $10 \mathrm{~cm}$ diameter and $150 \mathrm{~cm}$ height at a bed height of $100 \mathrm{~cm}$. The sample was pumped into the column by a peristaltic pump at a constant flow rate of $5 \mathrm{mLmin}^{-1}$. The column was operated for 4 hours and the effluent was then collected at the bottom to be analyzed. The temperature and particle size were fixed at an optimum constant of $28^{\circ} \mathrm{C}$ and $1 \mathrm{~mm}$ of adsorbent size. Two pieces of glass wool were placed on the top and bottom of the column to prevent the clogging of the adsorbent into the drainage area and to increase the distribution area of the solution onto the adsorbent surface. The pressure in the column was maintained at an atmospheric pressure by leaving the top of the column open. The effluent solution from the column was collected and analyzed according to the Standard Methods for the Examination of Water and Waste Water ${ }^{9}$. The result was then compared with the wastewater analysis before the experiment and Standard B limitation for discharge of industrial effluent or mixed effluent by DOE Malaysia. Figure 2 shows the schematic drawing of the experiment, respectively.

\section{Scanning electron microscopy (SEM) analysis}

Microscopy observations throughout the Scanning Electron Microscope (SEM) were achieved by a Hitachi VP-SEM S-3400N scanning electron microscopy (SEM). Samples of the adsorbent were first adhered on the surface of the carbon tape and were mounted on an Aluminium stub, which were then sputter-coated with a thin layer of gold by using the sputter coater Polaron E-1500. This has been completed in order to keep away from the electrostatic charging throughout the observation works. 


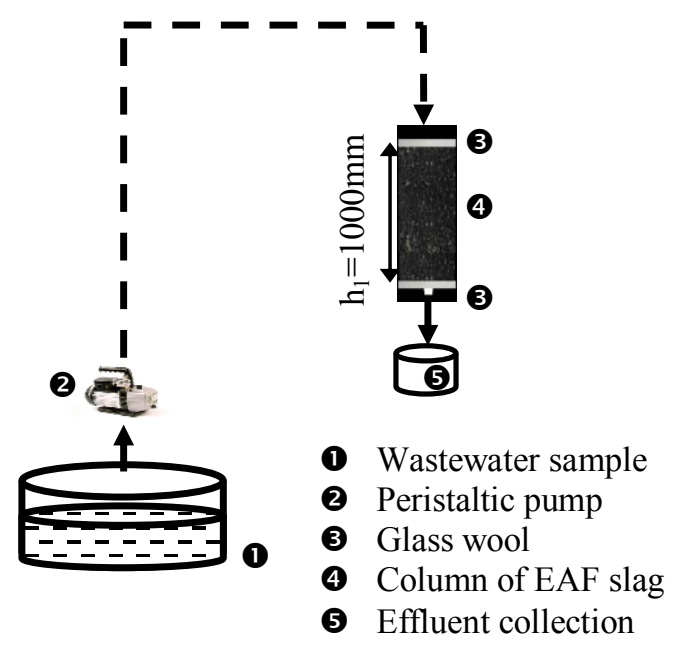

Figure 2. Schematic Drawing of the EAFS Column.

\section{FT-IR analysis}

A Fourier Transform Infrared Spectrometer measures the vibrational spectrum of a molecule. Any molecule that exhibits a change in a dipole moment change due to vibration, rotation, stretching or bending of bonds adsorbs the characteristics frequencies of the energy in the infrared range. The adsorption peaks can provide qualitative and quantitative information about the compounds that are being analyzed. In this study, measurements were carried out using the Perkins Elmer Spectrum @ 2000 FTIR spectrophotometer.

\section{Results and Discussion}

Scanning electron microscopy (SEM) analysis

The surface image of the electric arc furnace slag (EAFS) samples before and after the adsorption process were captured by scanning the electron microscopic (SEM) to observe the morphology of the EAFS, as shown in Figure 3. The SEM images revealed that the pores within the EAFS particles were heterogeneous with the large microspores and inter-particle cavities. It is observed that the pore size of raw EAFS ranged between 1.55 to $2.12 \mu \mathrm{m}$. After the adsorption, the pore size average reduced to $0.3 \mu \mathrm{m}$. It is concluded that the pore size changed with the incorporation or adsorption of the metal ions ${ }^{10}$.
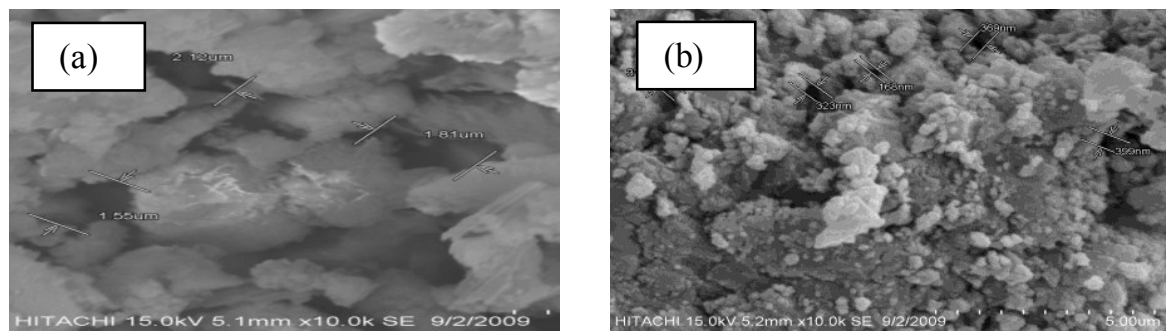

Figure 3. Scanning Electron Micrograph (SEM) of EAFS (a) before adsorption (b) after adsorption. 


\section{FTIR analysis}

The FTIR spectra were recorded before and after the adsorption in the fixed bed column studies in order to determine the main functional groups of EAFS that participate in the Manganese adsorption. Figure 4 shows the FTIR spectra analysis of the EAFS before and after the adsorption. An adsorption peak of around $3611.6 \mathrm{~cm}^{-1}$ represented the hydrated minerals such as $\mathrm{Ca}(\mathrm{OH})_{2}$ and the peak of around $3532.0 \mathrm{~cm}^{-1}$ indicates the $\mathrm{S}-\mathrm{O}$ stretch such as Gypsum. The peak of around $1491.9 \mathrm{~cm}^{-1}$ corresponds to the $\mathrm{C}-\mathrm{O}$ asymmetric stretching, whereas a peak at $1408.4 \mathrm{~cm}^{-1}$ may be due to the bonding in the $\mathrm{CO}_{3}{ }^{2-}$ ions, indicating the presence of some sort of a carbonated mineral, possibly due to the adsorption of $\mathrm{CO}_{2}$ from the atmosphere. The peaks of $971.0 \mathrm{~cm}^{-1}$ and $910.4 \mathrm{~cm}^{-1}$ are the $\mathrm{Si}-\mathrm{O}$ and $\mathrm{Al}-\mathrm{O}$ stretching, while the peaks of $875 \mathrm{~cm}^{-1}$ to $854.8 \mathrm{~cm}^{-1}$ are the $\mathrm{C}-\mathrm{O}$ bending ${ }^{11}$.

The peak changes observed after the adsorption may indicate that these functional groups are likely to participate in the metal binding. From Figure 4, it can be concluded that there is a shift in the functional groups peaks after the adsorption process. There is a shift in the hydroxide group from $3611.6 \mathrm{~cm}^{-1}$ to $3692 \mathrm{~cm}^{-1}$, sulphonyl group from $3532.0 \mathrm{~cm}^{-1}$ to 3608 $\mathrm{cm}^{-1}$, alcohol group from $1491.9 \mathrm{~cm}^{-1}$ to $1527.5 \mathrm{~cm}^{-1}$ while the carbonate group shifts from $1408.4 \mathrm{~cm}^{-1}$ to $1439 \mathrm{~cm}^{-1}$. The Al-O and Si-O stretching shifts from $971 \mathrm{~cm}^{-1}$ and $910.4 \mathrm{~cm}^{-1}$ to $1028 \mathrm{~cm}^{-1}$ and $979.5 \mathrm{~cm}^{-1}$ respectively. Lastly, ether group shifts from $\left(875 \mathrm{~cm}^{-1}\right.$ to 854.8 $\left.\mathrm{cm}^{-1}\right)$ to $\left(946.8 \mathrm{~cm}^{-1}\right.$ to $\left.924 \mathrm{~cm}^{-1}\right)$. Shifts of the functional groups could correspond to the complexation and coordination of these groups with the metal ions ${ }^{12}$.

(a)

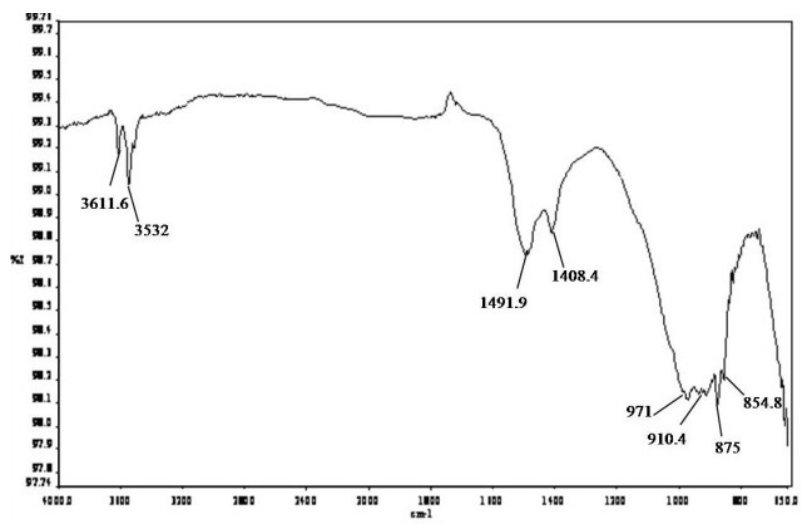

(b)

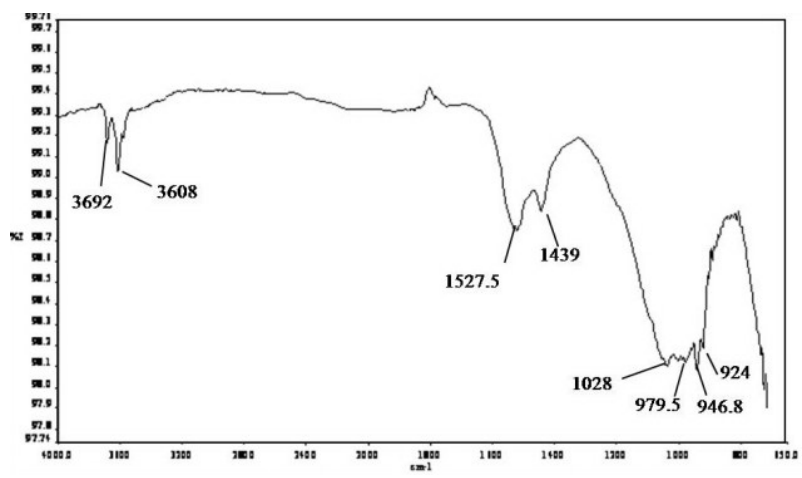

Figure 4. FTIR spectra of EAFS (a) before adsorption (b) after adsorption. 
Table 2. Characteristic of Influent and Effluent of still making plant.

\begin{tabular}{|c|c|c|c|c|}
\hline Parameter & Unit & Before Treatment & $\begin{array}{c}\text { After } \\
\text { Treatment }\end{array}$ & Standard B \\
\hline $\mathrm{pH}$ & - & 6.3 & 8.33 & $5.5-9.0$ \\
\hline Temperature & ${ }^{\circ} \mathrm{C}$ & 26.5 & 26.4 & 40 \\
\hline $\mathrm{BOD}_{5}$ & $\mathrm{mgL}^{-1}$ & 80.4 & 1.6 & 50 \\
\hline COD & $\mathrm{mgL}^{-1}$ & 361 & 6.3 & 200 \\
\hline $\begin{array}{c}\text { Total Suspended } \\
\text { Solids }\end{array}$ & $\mathrm{mgL}^{-1}$ & 345 & $\mathrm{ND}(<2)$ & 100 \\
\hline Cyanide as $\mathrm{C}_{\mathrm{N}}$ & $\mathrm{mgL}^{-1}$ & $\mathrm{ND}(<0.01)$ & $\mathrm{ND}(<0.01)$ & 0.10 \\
\hline Boron as B & $\mathrm{mgL}^{-1}$ & 0.5 & $\mathrm{ND}(<0.2)$ & 4.0 \\
\hline Phenol & $\mathrm{mgL}^{-1}$ & $\mathrm{ND}(<0.001)$ & ND $(<0.001)$ & 1.0 \\
\hline Free Chlorine as $\mathrm{Cl}_{2}$ & $\mathrm{mgL}^{-1}$ & $\mathrm{ND}(<0.01)$ & $\mathrm{ND}(<0.01)$ & 2.0 \\
\hline Sulphide as S & $\mathrm{mgL}^{-1}$ & $\mathrm{ND}(<0.01)$ & $\mathrm{ND}(<0.01)$ & 0.50 \\
\hline Oil \& Grease & $\mathrm{mgL}^{-1}$ & $\mathrm{ND}(<0.5)$ & $\mathrm{ND}(<0.5)$ & 10.0 \\
\hline Cadmium as $\mathrm{Cd}$ & $\mathrm{mgL}^{-1}$ & $\mathrm{ND}(<0.001)$ & $\mathrm{ND}(<0.001)$ & 0.02 \\
\hline Chromium as $\mathrm{Cr}^{3+}$ & $\mathrm{mgL}^{-1}$ & $\mathrm{ND}(<0.03)$ & $\mathrm{ND}(<0.03)$ & 1.0 \\
\hline Chromium as $\mathrm{Cr}^{6+}$ & $\mathrm{mgL}^{-1}$ & $\mathrm{ND}(<0.005)$ & ND $(<0.005)$ & 0.05 \\
\hline Lead as $\mathrm{Pb}$ & $\mathrm{mgL}^{-1}$ & $\mathrm{ND}(<0.01)$ & $\mathrm{ND}(<0.01)$ & 0.5 \\
\hline Copper as $\mathrm{Cu}$ & $\mathrm{mgL}^{-1}$ & 0.83 & 0.07 & 1.0 \\
\hline Manganese as Mn & $\mathrm{mgL}^{-1}$ & 1.56 & 0.03 & 1.0 \\
\hline Nickel as Ni & $\mathrm{mgL}^{-1}$ & $\mathrm{ND}(<0.01)$ & $\mathrm{ND}(<0.001)$ & 1.0 \\
\hline Zinc as Zn & $\mathrm{mgL}^{-1}$ & 4.02 & 0.01 & 2.0 \\
\hline Iron as $\mathrm{Fe}$ & $\mathrm{mgL}^{-1}$ & 23.3 & 0.08 & 5.0 \\
\hline Mercury as $\mathrm{Hg}$ & $\mathrm{mgL}^{-1}$ & $\mathrm{ND}(<0.001)$ & ND $(<0.001)$ & 0.05 \\
\hline Arsenic as As & $\mathrm{mgL}^{-1}$ & $\mathrm{ND}(<0.001)$ & ND $(<0.001)$ & 0.10 \\
\hline Tin as $\mathrm{Sn}$ & $\mathrm{mgL}^{-1}$ & $\mathrm{ND}(<0.002)$ & $\mathrm{ND}(<0.002)$ & 1.0 \\
\hline Silver as Ag & $\mathrm{mgL}^{-1}$ & $\mathrm{ND}(<0.02)$ & $\mathrm{ND}(<0.02)$ & 1.0 \\
\hline Aluminium as $\mathrm{Al}$ & $\mathrm{mgL}^{-1}$ & 1.46 & $\mathrm{ND}(<0.01)$ & 15 \\
\hline Fluoride as F & $\mathrm{mgL}^{-1}$ & 1.44 & $\mathrm{ND}(<0.02)$ & 5.0 \\
\hline $\begin{array}{c}\text { Ammoniacal Nitrogen } \\
\text { as } N\end{array}$ & $\mathrm{mgL}^{-1}$ & 1.35 & 0.35 & 20 \\
\hline Barium as $\mathrm{Ba}$ & $\mathrm{mgL}^{-1}$ & $\mathrm{ND}(<0.05)$ & $\mathrm{ND}(<0.05)$ & 2.0 \\
\hline Colour & ADMI & 12 & $\mathrm{ND}(<5)$ & 200 \\
\hline Formaldehyde & $\mathrm{mgL}^{-1}$ & $\mathrm{ND}(<0.2)$ & $\mathrm{ND}(<0.2)$ & 2.0 \\
\hline Appearance & - & $\begin{array}{l}\text { Clear Liquid with } \\
\text { suspended solid }\end{array}$ & Clear liquid & - \\
\hline
\end{tabular}

ND: Not detected.

Analysis of raw wastewater

Industrial wastewater contains several types of contaminations such as dissolved organic materials, suspended particles as well as oil and grease. These ions have different chemical and physical characteristics such as ionic size, ionic charge, electronegativity and reactivity in which can influence the adsorption process. These metal ions may act as a catalyst or an inhibitor, interacting with other metals in the adsorption process. As listed in Table 2, the major metals identified in the sample were copper, manganese, zinc, iron and aluminum. It is observed that Iron has the highest concentration of $23.3 \mathrm{mgL}^{-1}$, followed by zinc and manganese with 4.02 and $1.56 \mathrm{mgL}^{-1}$, respectively. These concentration values exceed the maximum levels of the Standard B limitations for discharge of industrial effluents. 
According to Standard B, the maximum concentrations of iron, zinc and manganese in the effluent are 5.0, 2.0 and $1.0 \mathrm{mgL}^{-1}$, respectively. The removal of Biochemical Oxygen Demand (BOD), Chemical Oxygen Demand (COD) and Total Suspended Solids (TSS) was also studied using the EAFS as an adsorbent. It is observed from Table 2 that the values of BOD, COD and TSS of the wastewater before treatment were 80.4, 361 and $345 \mathrm{mgL}^{-1}$ which exceeded the DOE Standard B limitation.

The analysis of the effluent collected after the fixed bed column test showed that there has been a great reduction in $\mathrm{BOD}, \mathrm{COD}$, TSS, Boron, copper, manganese, zinc, iron, aluminum, fluoride and ammoniacal nitrogen, as shown in Table 2. The TSS value decreased from $345 \mathrm{mgL}^{-1}$ to almost an undetectable value. The BOD and COD values were decreased from 80.4 and $361 \mathrm{mgL}^{-1}$ to 1.6 and $6.3 \mathrm{mgL}^{-1}$, respectively. Furthermore, the concentration of heavy metals also reduced to the standard B limitations for the discharge of the industrial effluent enforced by the Department of Environment Malaysia (DOE).

An increase in the effluent $\mathrm{pH}$ from 6.3 to 8.3 was observed. This can be due to the hydration of the slag composition. Major hydration reactions may occur with calcium oxide, magnesium oxide, calcium silicates and calcium aluminates as following ${ }^{13}$.

$$
\begin{gathered}
\mathrm{CaO}+\mathrm{H}_{2} \mathrm{O} \rightarrow \mathrm{Ca}(\mathrm{OH})_{2} \\
\mathrm{MgO}+\mathrm{H}_{2} \mathrm{O} \rightarrow \mathrm{Mg}(\mathrm{OH})_{2} \\
2 \mathrm{Ca}_{2} \mathrm{SiO}_{4}+4 \mathrm{H}_{2} \mathrm{O} \rightarrow 3 \mathrm{CaO} .2 \mathrm{SiO}_{2} \cdot 3 \mathrm{H}_{2} \mathrm{O}+3 \mathrm{Ca}(\mathrm{OH})_{2} \\
2 \mathrm{Ca}_{3} \mathrm{SiO}_{5}+6 \mathrm{H}_{2} \mathrm{O} \rightarrow 3 \mathrm{CaO} .2 \mathrm{SiO}_{2} \cdot 3 \mathrm{H}_{2} \mathrm{O}+3 \mathrm{Ca}(\mathrm{OH})_{2} \\
\mathrm{CaO} .7 \mathrm{Al}_{2} \mathrm{O}_{3}+12 \mathrm{H}_{2} \mathrm{O} \rightarrow \mathrm{CaO} . \mathrm{Al}_{2} \mathrm{O}_{3} \cdot 6 \mathrm{H}_{2} \mathrm{O}+6 \mathrm{Al}_{2} \mathrm{O}_{3} \cdot \mathrm{H}_{2} \mathrm{O}
\end{gathered}
$$

Application mode

In a fixed bed column system, EAFS may act as an adsorbent and also as a physical filter. With regard to the average pore size of EAFS $(1-2 \mu \mathrm{m})$ the reduction of TSS in the effluent was due to both the adsorption and filtration modes of EAFS. The EAFS also acted as a media filter that trapped the suspended solids that have a particle size greater than the pore size of the adsorbent. A decrease in the TSS and the amount of ions inside the wastewater, have also contributed in the reduction of COD and BOD ${ }^{14}$.

In addition, it is observed that EAFS had the ability to adsorb various heavy metals with different physical and chemical properties in the adsorption system. These metals may be adsorbed by means of physical adsorption and chemical adsorption, depending on the characteristics of the metal ${ }^{15}$. The presence of various types of metals with a different charge increased the competition of the metal ions to react with the active sites on the surface of the adsorbent. The differences in the amount of removal of each metal ion from the wastewater can be explained by the interaction of metal ions on each other and the displacement effects. Each metal has a unique electronegativities, ionic size and bond strength which influence the adsorption capacity of the EAFS ${ }^{16-17}$. Therefore, the presence of another metal acts as an inhibitor for the adsorption of another metal. Iron showed the highest affinity onto the EAFS. This could be due to the stability of the bond formation between the surface of the slag and the ionic metal. Besides, the high valency of +3 , compared to other metals contained in the wastewater, contributed to the strength of the bond formation with the functional groups on the surface of the EAFS. The strong bond formation also reduces the rate of desorption in the adsorbent and hence enhance the rate of the adsorption capacity ${ }^{18}$.

The reduction in the organic and inorganic compounds in the water reduces the rate of the decomposition of the bacteria by the biological and chemical oxidation. Thus, less oxygen is consumed by the oxidizing bacteria and therefore the amount of dissolved oxygen in the water is sufficient for the survival of aquatic lives. 


\section{Conclusion}

Electric arc furnace slag (EAFS) was used to treat the raw wastewater from steel industry containing a high heavy metals concentration as well as BOD, COD and TSS values exceeding the standard B limitations. The results showed that the EAFS was effective in reducing the effluent parameters to the Malaysia DOE Standard B limitations. It is also confirm that the EAFS was effective in the removal of heavy metals via adsorption and TSS removal as a filter bed.

\section{Acknowledgment}

The researchers would like to thank the Southern Steel Berhad for the supply of EAF slag and raw wastewater.

\section{References}

1. Seneviratne M, Harvison, J. 2011. Available at http://www.environment.gov.au/water/publications/urban/weo-manufacturing-steelguide.html (assessed on 21 February 2011).

2. Metcalf and Eddy, Wastewater Engineering, 4th ed., McGraw-Hill, New York, 2002.

3. Sponza D, Karaolu N, Environ. Int. 2002, 27(7), 541-553.

4. Gadd G M, Griffiths A, J Microorganisms and heavy metal toxicity. Microb. Ecol. 1977 4(4), 303-317.

5. Namasivayam, Ranganathan K, Environ. Pollut. 1993, 82(3), 255-261.

6. Ortiz N, Pires M A F, Bressiani J C, Waste Manage. 2001, 21(7), 631-635.

7. Do - Hyung Kim, Min - Chul Shin, Hyun - Doc Choi, Chang - Seo, Kitae Baek, Desalination. 2008, 223(1-3), 283 - 289.

8. Xue Y, Hou H, Zhu S, J Hazard Mater. 2009, 162(1), 391-401.

9. Lenore S, Clescerl E, Arnold E, Greenberg Andrew D E, 21st ed. Standard Methods for Examination of Water and Wastewater, 21 st ed., American Public Health Association, Washington, DC, 2005.

10. Maziad N A, Polym. Plast. Technol. Eng. 2004, 43(4), 1157-1176.

11. Yang R T, Adsorbents: Fundamentals and Applications Wiley-Interscience, New Jersey, 2003, pp: 18-40.

12. Liu S Y, Xu Y Y, Gao J, Lu C W, Yang Y J, Appl. Mech. Mater. 2011, 48, 844-847.

13. Yan J, Moreno L, Neretnieks I, Waste Manage. 2000, 20 (2-3), 217-223.

14. Xiong J B, He Z L, Mahmood Q, Liu D, Yang X, Islam E, J. Hazard. Mater. 2008, 152 (1), 211-215.

15. Taha G M, Mosaed T M, J.Chem. Biodiversity. 2010, 7, 878-886.

16. Gomes P C, Fontes M P F, da Silva A G, de Mendonca E, Netto A R, Soil Sci. Soc. Am. J. 2001, 65(4), 1115-1121.

17. Forbes E A, Posner A M, Quirk J P, Eur. J. Soil Sci. 1976, 27(2), 154-166.

18. Sag Y, Kutsal T, Process Biochem.1996, 31(6), 573-585. 


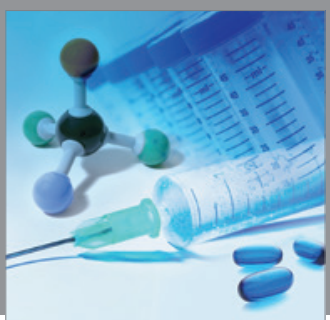

International Journal of

Medicinal Chemistry

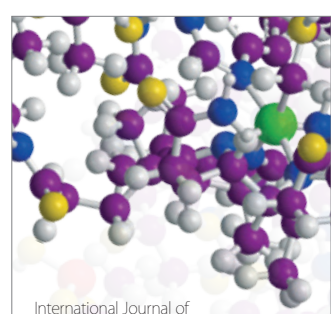

Carbohydrate Chemistry

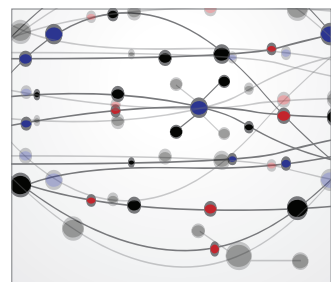

The Scientific World Journal
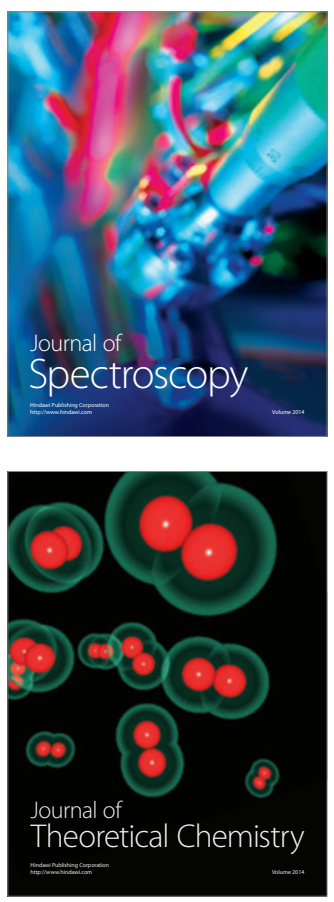
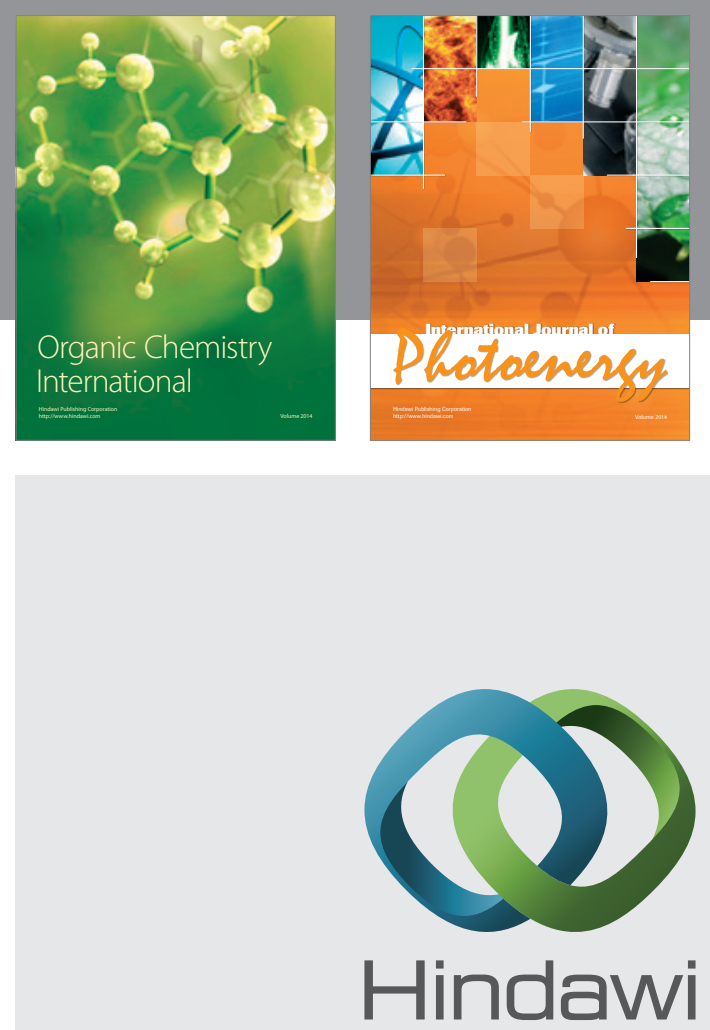

Submit your manuscripts at

http://www.hindawi.com
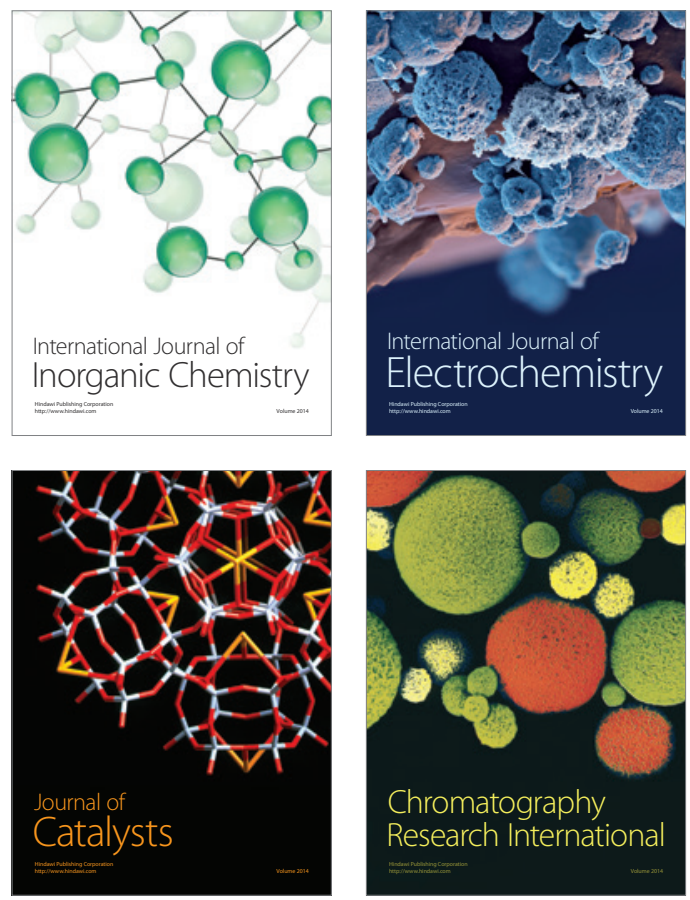
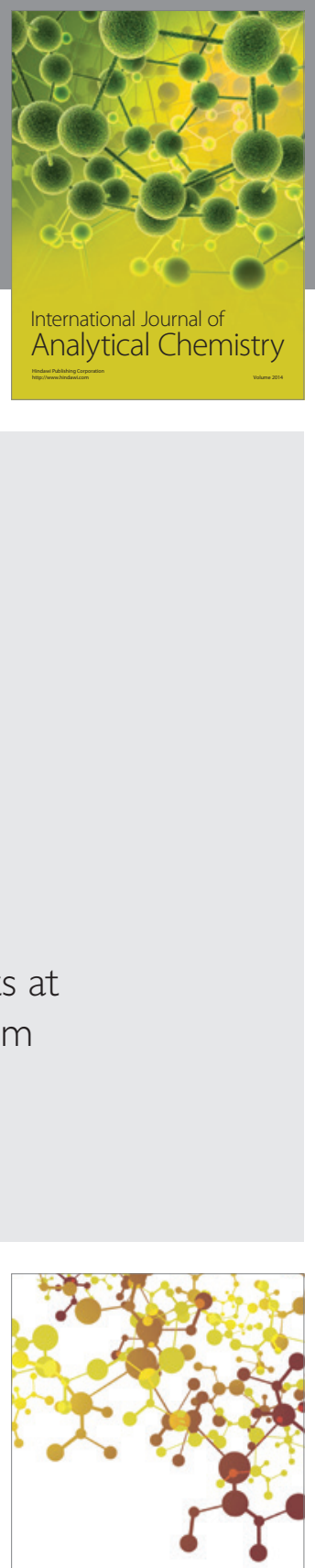

Journal of

Applied Chemistry
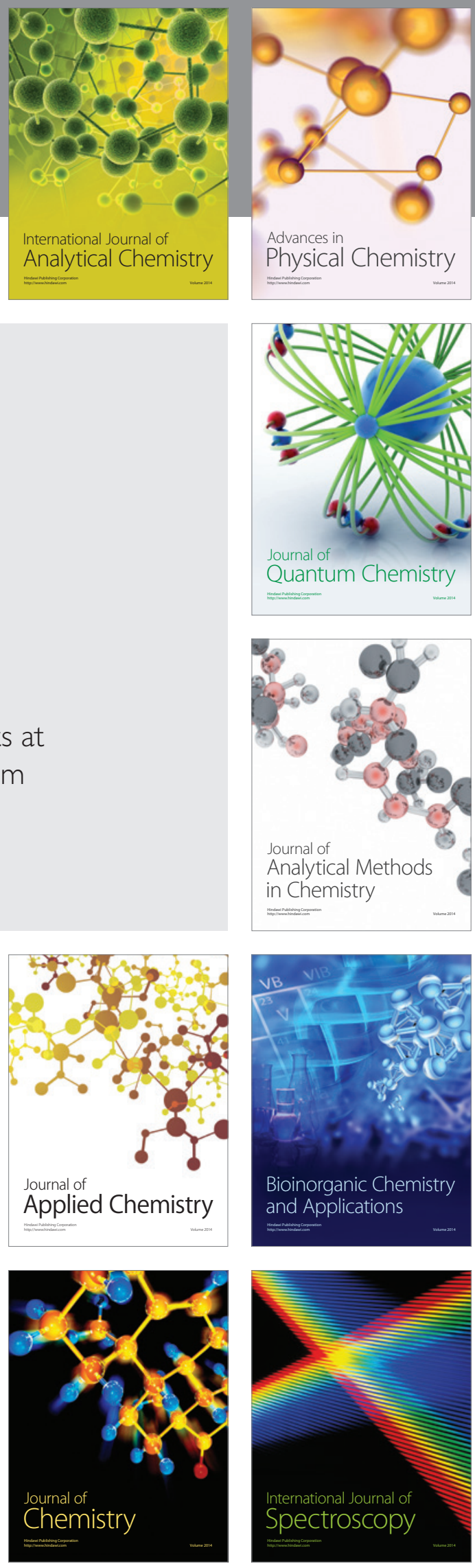